\title{
STUDI PENERAPAN HACCP (HAZARD ANALYSIS CRITICAL CONTROL POINT) PADA PROSES PENGOLAHAN MI SAGU
}

\author{
Miskiyah, Widaningrum, dan Hetty Herawati
}

\begin{abstract}
Sago is one of local food at some regions in Indonesia. Processing technology of sago become noodle is one way to vary sago processing product. The main factor that effect sago noodle processing are quality, self life, and limited marketing of sago noodle. Thus to make sago noodle assurance, HACCP plan is needed. This study purposes to assess the HACCP system guidelines which are suitable for processing of sago noodle base on 7 principles system guidelines. Result of the study shown that sago noodle processing have chemical hazard (heavy metal contamination, coloring and textures), and microbiological hazard (pathogens from operator such as Streptococcus; also water source such as Coliform and Shigella). As conclusion, HACCP system guidelines on sago noodle processing is very important to develop quality and safety assurance.
\end{abstract}

Keywords: HACCP, processing, sago noodle

\section{PENDAHULUAN}

Sagu merupakan salah satu pangan pokok di beberapa kawasan di Indonesia, terutama Kawasan Timur Indonesia (KTI). Sebagai salah satu pangan lokal, sagu umumnya diolah dari resep yang dikenal secara turun temurun oleh masyarakat setempat. Hasil olahannya memiliki rasa yang relatif sesuai dengan selera mayarakat setempat. Beberapa jenis pangan tradisional dari sagu diantaranya adalah kapurung, papeda, dan lain-lain.

Sagu pada dasarnya adalah hasil ekstraksi pati dari batang sagu Metroxylon sp. Untuk mendapatkan pati, pohon sagu umur 5-8 tahun ditebang pada pangkal batangnya, kulit luar dibuang dan bagian dalam dipotong-potong untuk diambil empulurnya dengan cara diparut. Hasil parutan direndam sambil diremas/diaduk kemudian disaring. Hasil saringan dibiarkan mengendap untuk diambil pati sagunya.

Sebagai pangan tradisional, sagu berpotensi untuk dikembangkan sebagai pangan alternatif. Namun terdapat berbagai kendala untuk pengembangannya. Hal tersebut karena segmen pasar yang terbatas, yang berkaitan dengan preferensi konsumsi pangan tradisional yang bersangkutan. Teknologi pengolahan mi sagu perlu diperbaiki agar produk tersebut dapat diterima oleh lingkup konsumen yang luas.

Teknologi pengolahan sagu menjadi mi merupakan salah satu upaya untuk menganekaragamkan produk olahan sagu dan membuka peluang pasar bagi pangan pokok/sumber karbohidrat di suatu wilayah tertentu (lokal). Di daerah Jawa Barat terutama Bogor, Sukabumi, dan Cianjur sagu sebagai makanan pokok dikonversi dalam bentuk mie yang dikenal dengan sebutan mi gleser (Bogor) atau mi leor (Sukabumi).

Balai Besar Penelitian dan Pengembangan Pascapanen Pertanian pada tahun 2003-2005 telah melakukan penelitian teknologi pangan tradisional prospektif pangan pokok untuk mengembangkan teknologi inovatif pengolahan mie sagu. Penelitian ini bertujuan untuk membantu masyarakat dalam upaya untuk memperbaiki teknologi pengolahan pangan tradisional atau pangan lokal. Hal ini akan membuka peluang pasar bagi komoditas pangan lokal dan mempercepat terciptanya katahanan pangan Nasional.

Sampai dengan tahun 2005, penelitian yang telah dilakukan oleh BB Litbang Pascapanen telah berhasil memperbaiki kualitas sagu lempeng, dan menguji tingkat penerimaan mi sagu di wilayah produsen sagu (studi kasus di Sulawesi Selatan). Produk olahan sagu menjadi mi terhambat oleh kualitas yang beragam (tergantung bahan baku dan proses pengolahannya), umur simpan yang relatif singkat, dan pemasaran yang terbatas. Hal tersebut kemungkinan disebabkan oleh belum adanya sistem jaminan mutu dan keamanan pangan. Padahal sebagai makanan olahan, mi sagu harus terjamin keamanannya sehingga tidak membahayakan bagi kesehatan manusia.

HACCP merupakan suatu pendekatan untuk mencegah dan mengontrol penyakit karena keracunan makanan. Sistem ini dirancang untuk mengidentifikasi bahaya yang berhubungan dengan beberapa tahapan produksi, prosesing atau penyiapan makanan, serta memperkirakan resiko yang akan terjadi dan menentukan prosedur operasi untuk 
prosedur kontrol yang efektif (Bryan, 1992). Sistem HACCP merupakan alat yang tepat untuk menetapkan sistem pengendalian karena berfokus pada pencegahan dari pada pengujian produk akhir. HACCP dapat diterapkan pada seluruh rantai pangan dari produk primer sampai pada konsumsi akhir dan penerapannya harus dipandu oleh bukti secara ilmiah terhadap resiko kesehatan manusia.

\section{BAHAN DAN METODE}

Penelitian dilakukan pada tahun 2003. Proses pengolahan $\mathrm{mi}$ sagu dilakukan dengan melakukan survei di lokasi pengrajin mi sagu yang ada di kabupaten Sukabumi, untuk mengetahui proses pengolahan mi yang dilakukan di lapang. Sedangkan perbaikan proses dilakukan di Laboratorium Pascapanen Bogor.

Perlakuan penelitian ini adalah penerapan HACCP dan non HACCP, dengan diulang 3 kali. Pengamatan dilakukan terhadap bahan baku (pati sagu, tawas, pewarna, air), analisa proses (pembuatan biang, suspensi pati sagu, pengadukan, pencetakan, pemasakan, perendaman, dan penirisan).

Studi HACCP pada proses pengolahan mi sagu menggunakan Panduan Penyusunan Rencana HACCP (BSN-Pedoman 1004-1999). Alat bantu lain yang digunakan adalah daftar bahan baku dan bahan penunjang, bagan alir proses produksi, tabel penentuan tingkat resiko, dan CCP decision tree (pohon keputusan CCP). Gambar 1 menunjukkan pohon keputusan yang digunakan sebagai alat bantu untuk menentukan CCP atau titik kendali kritis, dimana pohon keputusan harus menyatakan pendekatan pemikiran yang logis (masuk akal).

Sedangkan proses penyusunannya berdasarkan 7 prinsip sistem $H A C C P$ yang direkomendasikan oleh Standar Nasional Indonesia (1998) yang dikeluarkan oleh BSN (1999), yang meliputi:

1. Prinsip 1: Analisis bahaya dan pencegahannya

2. Prinsip 2: Identifikasi Critical Control Points (CCPS) di dalam proses

3. Prinsip 3: Menetapkan Batas Kritis untuk setiap CCP

4. Prinsip 4: Menetapkan cara pemantauan CCP

5. Prinsip 5: Menetapkan tindakan koreksi

6. Prinsip 6: Menyusun Prosedur Verifikasi
7. Prinsip 7: Menetapkan prosedur pencatatan (dokumentasi)

Analisa bahaya dilakukan dengan mengidentifikasi semua bahaya baik yang terdapat pada bahan baku maupun tahapan proses. Bahaya yang teridentifikasi kemudian disusun dalam sebuah tabel disertai sumber bahaya, tingkat resiko, dan tindakan pencegahannya. Tingkat resiko ditentukan berdasarkan seberapa besar akibat yang ditimbulkan oleh suatu bahaya dan seberapa sering bahaya tersebut mungkin terjadi. Penentuan CCP didasarkan pada pertimbangan tingkat resiko; dan memerlukan pengendalian supaya tidak berbahaya bagi kesehatan manusia. Tahapan proses yang tidak termasuk $C C P$, dapat termasuk Control Point (CP) yang berarti tahapan tersebut apabila tidak dikendalikan dengan baik dapat menyebabkan kecacatan dari segi kualitas.

\section{HASIL DAN PEMBAHASAN}

\subsection{Analisa Bahaya Bahan Baku Pembuatan Mi Sagu}

Bahan baku yang digunakan dalam pembuatan mi sagu antara lain pati sagu, air, pewarna, bahan pengeras (tawas), dan minyak kacang (Tabel 1). Sedangkan proses ekstraksi sagu menjadi pati sagu sebagai bahan dasar mi sagu dapat dilihat pada Gambar 2.

Pati sagu mengandung bahaya kimia dan mikrobiologi yang berasal dari air. Pada ekstraksi pati sagu, air digunakan untuk merendam batang sagu dan mencuci pati basah (Gambar 2). Air menjadi berbahaya jika tidak bersih atau sudah tercemar oleh logam berat. Air dapat menjadi bahaya mikrobiologi, jika air tersebut sudah tercemar oleh bakteri koliform, Eschericia coli, Vibrio cholerae, dan Shigella sp. Keberadaan fekal koliform pada air merupakan indikasi adanya kontaminasi fekal dan bakteri enterik lainnya (Schmitt dkk., 1997). Dalam proses produksi pengolahan makanan tidak diperbolehkan menggunakan air permukaan, tetapi harus air sumur/PAM. Air sumur/PAM lebih sedikit mengandung mikroorganisme dari pada air permukaan, dan dalam penggunaannya air ini selalu mengalami perebusan terlebih dahulu sehingga aman dikonsumsi (Waryat dkk: 2004). Bahaya mikroorganisme lain berasal dari jamur, jika proses pengeringan tidak sempurna sehingga kadar air pada pati sagu masih cukup tinggi, maka hal tersebut memungkinkan tumbuhnya berbagai macam jamur sehingga berdasarkan pertimbangan tingkat resiko tersebut pati sagu ditetapkan sebagai CCP. 


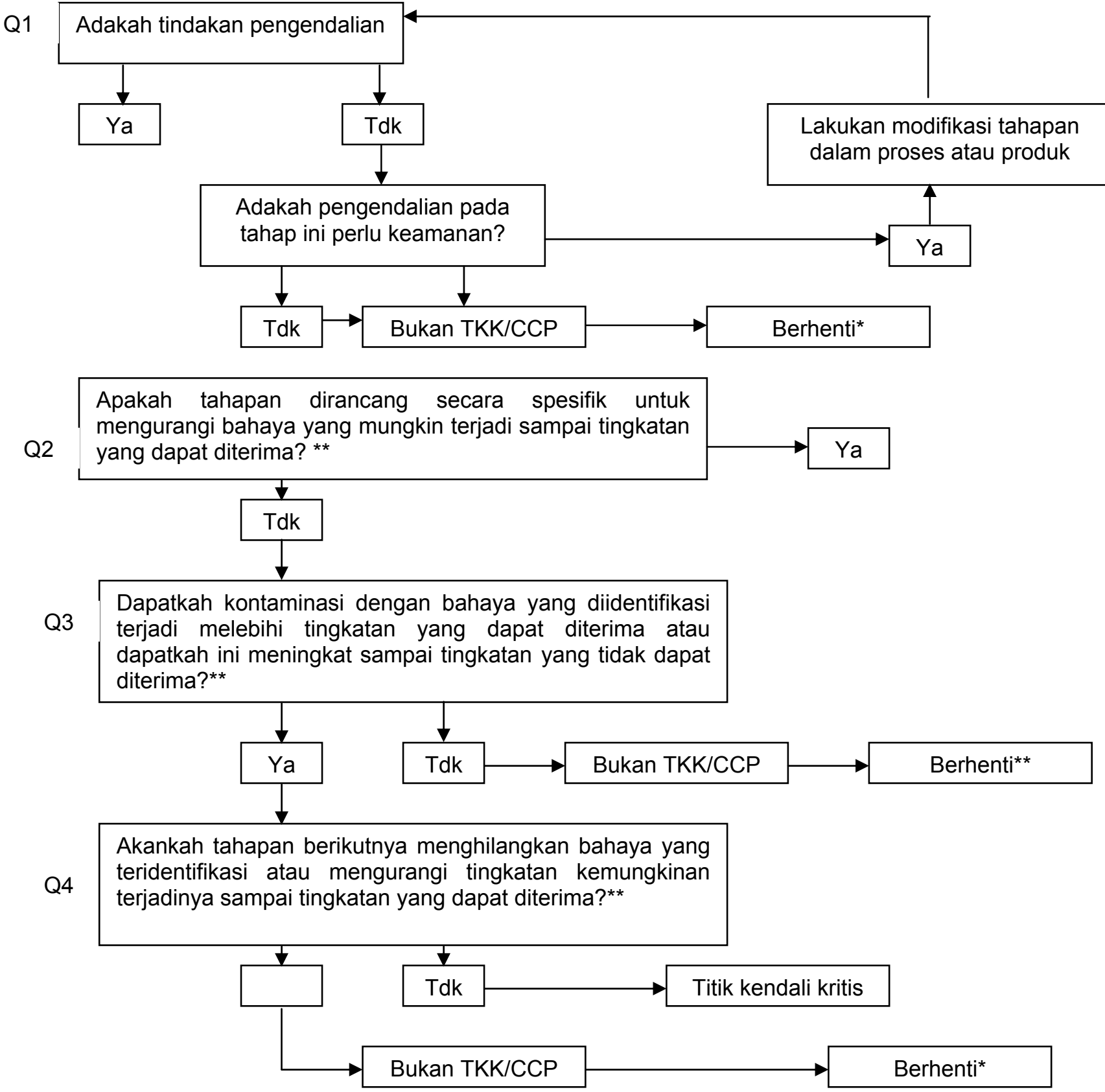

\section{Gambar 1 Pohon Keputusan CCP}

Tawas (Alum Potas) menjadi CP jika dosis yang digunakan berlebihan. Hal tersebut biasanya disebabkan oleh ketidakjelian yang dilakukan operator dalam penimbangan, sehingga dalam menambahkan tawas yang digunakan sebagai bahan pengeras penimbangan perlu dilakukan dengan benar. Pewarna menjadi $C P$ karena banyak penggunaan pewarna yang tidak tepat untuk ditambahkan pada adonan mi. Penggunaan pewarna yang tidak direkomendasikan untuk makanan (misalnya pewarna tekstil) akan mengakibatkan bahaya dan efek yang buruk bagi kesehatan. Minyak menjadi $C P$ karena adanya kontaminasi silang yang berasal dari mikrobia. Penambahan minyak untuk membuat adonan agar tidak lengket harus diperhatikan agar dilakukan sehigienis mungkin, karena akan mempengaruhi kualitas akhir dari produk mi yang dihasilkan. Monitoring dapat dilakukan dengan pengamatan secara visual terhadap minyak (ketengikan) pada setiap proses. 


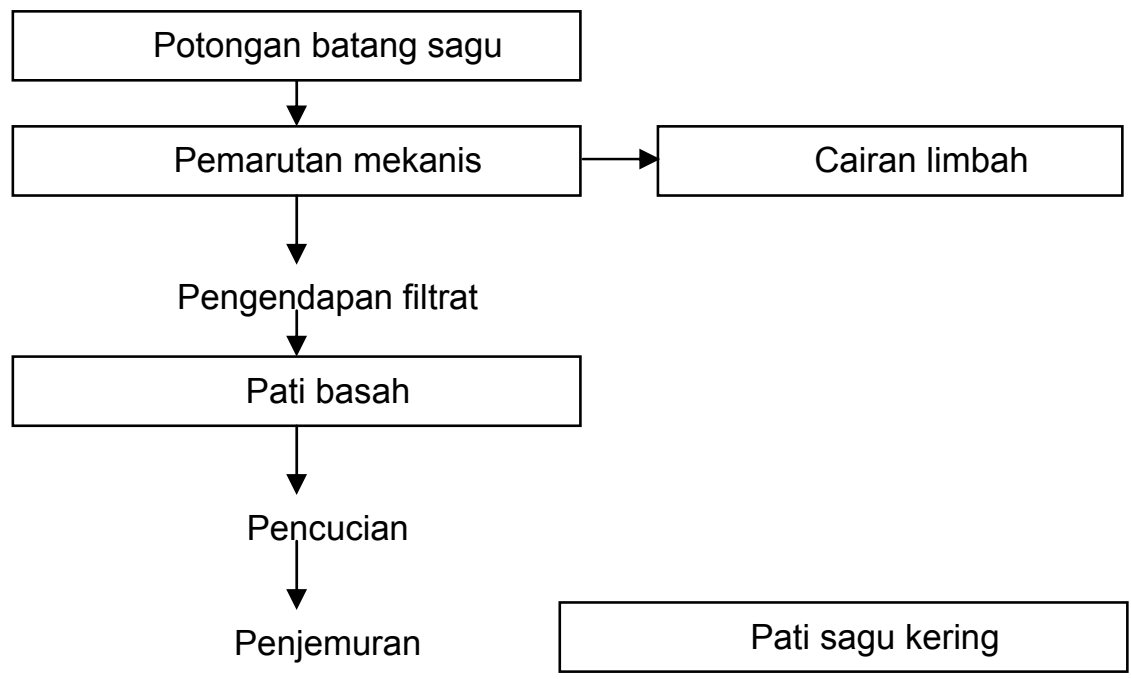

Gambar 2 Diagram Alir Proses Ekstraksi

Tabel 1 Analisis Bahaya Bahan Baku Mi Sagu

\begin{tabular}{|c|c|c|c|c|c|c|c|c|c|}
\hline \multirow[b]{2}{*}{ No } & \multirow[b]{2}{*}{$\begin{array}{c}\text { Bahan } \\
\text { Baku }\end{array}$} & \multirow[b]{2}{*}{ Bahaya } & \multicolumn{2}{|c|}{ Bahaya terhadap } & \multirow[b]{2}{*}{$\begin{array}{c}\text { Penyebab } \\
\text { bahaya }\end{array}$} & \multicolumn{3}{|c|}{ Penting tidaknya } & \multirow[b]{2}{*}{$\begin{array}{c}\text { Tindakan } \\
\text { Pengendalian }\end{array}$} \\
\hline & & & Keselamatan & Mutu & & $\begin{array}{c}\text { Peluang } \\
\text { (T/S/R) }\end{array}$ & $\begin{array}{c}\text { Keparahan } \\
\text { (T/S/R) }\end{array}$ & $\begin{array}{l}\text { Penting } \\
\text { /Tidak } \\
\text { (T/S/R) }\end{array}$ & \\
\hline & Sagu & $\begin{array}{l}\mathrm{K} \text { : Logam berat } \\
\mathrm{M}: \text { Jamur, } \\
\text { bakteri }\end{array}$ & $\sqrt{ }$ & $\sqrt{ }$ & $\begin{array}{l}\mathrm{K}: \text { residu logam } \\
\text { berat dlm air } \\
\mathrm{M}: \text { kontaminasi } \\
\text { selama proses } \\
\text { pengeringan }\end{array}$ & $\begin{array}{l}\mathrm{T} \\
\mathrm{T}\end{array}$ & $\begin{array}{l}\mathrm{T} \\
\mathrm{T}\end{array}$ & $\begin{array}{l}\mathrm{T} \\
\mathrm{T}\end{array}$ & $\begin{array}{l}\text { - penggunaan } \\
\text { air utk } \\
\text { perendaman, } \\
\text { pencucian, yg } \\
\text { bersih dan } \\
\text { higienis } \\
\text { - pengeringan } \\
\text { sampai KA yg } \\
\text { dipersyaratkan } \\
(<13 \%)\end{array}$ \\
\hline & $\begin{array}{l}\text { Tawas } \\
\text { (Pengeras) }\end{array}$ & $\begin{array}{l}\mathrm{K}: \text { dosis tdk } \\
\text { tepat/berlebihan }\end{array}$ & $\sqrt{ }$ & $\sqrt{ }$ & $\begin{array}{l}\text { Ketidakjelian } \\
\text { operator dalam } \\
\text { penimbangan }\end{array}$ & $\mathrm{R}$ & $\mathrm{R}$ & $\mathrm{R}$ & $\begin{array}{l}\text {-menimbang } \\
\text { dgn benar }\end{array}$ \\
\hline & Pewarna & $\begin{array}{l}\mathrm{K} \text { : Pewarna } \\
\text { buatan/sintetis }\end{array}$ & $\sqrt{ }$ & $\sqrt{ }$ & $\begin{array}{l}\text { Penggunaan } \\
\text { pewarna yg tdk } \\
\text { direkomendasikan } \\
\text { utk makanan }\end{array}$ & $\mathrm{R}$ & $\mathrm{R}$ & $\mathrm{R}$ & $\begin{array}{l}\text {-penggunaan } \\
\text { pewarna yg } \\
\text { diijinkan utk } \\
\text { makanan } \\
\text { (food grade) }\end{array}$ \\
\hline & Air & $\begin{array}{l}\mathrm{K} \text { : logam berat } \\
\mathrm{M}: \text { bakteri } \\
\text { E.coli, Shigella } \\
\text { sp., V. cholerae }\end{array}$ & $\sqrt{ }$ & $\checkmark$ & $\begin{array}{l}\text { K : Residu logam } \\
\text { berat dlm air } \\
\mathrm{M}: \text { Sbr air yg } \\
\text { digunakan tdk } \\
\text { bersih }\end{array}$ & $\mathrm{T}$ & $\mathrm{T}$ & $\mathrm{T}$ & $\begin{array}{l}\text {-tdk } \\
\text { menggunakan } \\
\text { air kotor } \\
\text {-tgk } \\
\text { menggunakan } \\
\text { air permukaan } \\
\text {-merebus air } \\
\text { sampai } \\
\text { matang }\end{array}$ \\
\hline
\end{tabular}

Keterangan: K : Kimia; M : Mikrobiologi; F : Fisik; T : Tinggi; S : Sedang; R : Rendah

\subsection{Analisa Bahaya pada Proses Pembuatan Mi Sagu}

Pembuatan mi sagu terdiri dari beberapa tahap yaitu pembuatan biang, pembentukan adonan, pencetakan, pemasakan, perendaman, dan penirisan (Gambar 2). Biang disiapkan dengan 30 cara menambahkan air mendidih ke dalam suspensi pati sagu yang ditambah dengan pewarna dan bahan pengeras sehingga membentuk gel. Selanjutnya kedalam biang ditambah sagu sambil terus diaduk secara manual atau secara mekanis dengan alat 
pengaduk 'molen' hingga adonan kalis dan siap dicetak. Setelah dicetak, mi dimasak dalam panci besar berisi air mendidih hingga terapung, diangkat dan direndam dalam air mengalir selama beberapa jam. Mi diangkat, ditiriskan, dan diberi minyak agar tidak lengket. Setelah beberapa saat mi siap dikemas untuk dipasarkan.

Berdasarkan pertimbangan tingkat resiko dan jawaban atas pertanyaan CCP decision tree, pada tahap proses produksi ini ditetapkan 2 tahap yang termasuk CCP dan 5 tahap yang termasuk CP. Tahapan yang termasuk CCP yaitu perendaman dan penirisan (Tabel 2).

Tahapan yang termasuk $C P$ ialah pembentukan biang, suspensi pati sagu, pengadukan, pencetakan, dan pemasakan (Tabel 3). Pembentukan biang menjadi penting karena merupakan tahap awal pembuatan mi sagu, yang akan menentukan kualitas mi sagu yang dihasilkan. Penggunaan air dan pati sagu yang berkualitas menjadi penting untuk menghindari adanya kontaminasi baik mikrobiologi maupun kimia. Proses ini dilakukan secara manual (menggunakan tenaga manusia), sehingga tangan operator dan peralatan yang digunakan harus bersih, dimana monitoring dilakukan dengan pemeriksaan secara visual pada setiap proses.

Suspensi pati menjadi CP karena bahan tambahan (pewarna dan pengeras/tawas) yang digunakan dalam suspensi harus benar-benar aman dan tidak berlebihan. Jika bahan tambahan tidak memenuhi syarat maka akan dihasilkan produk yang tidak aman. Pengadukan menjadi $C P$ karena menggunakan peralatan 'molen' yang bisa mengakibatkan adanya kontaminasi silang dengan peralatan. Proses ini mensyaratkan tangan operator harus selalu bersih dan peralatan harus selalu dicuci setelah dipakai.

Pencetakan menjadi CP karena penggunaan mesin pencetak mi yang tidak bersih akan mengakibatkan adanya kontaminasi silang antara peralatan dengan adonan mi sagu, sehingga peralatan yang digunakan harus selalu bersih dan higienis.
Pemasakan menjadi $C P$ karena kemungkinan terjadi kontaminasi logam berat yang berasal dari air yang digunakan untuk memasak. Pemasakan dimonitor dengan penggunaan sumber air yang bagus (air sumur/PAM). Frekuensinya dilakukan setiap proses. Jika didapati air kurang memenuhi syarat maka harus segera diganti dengan air yang bebas kontaminan. Proses pemasakan dilakukan selama 1 menit, yang ditandai dengan helain mi yang mengapung. Jika pemasakan kurang (<1 menit) mi akan kurang matang, dan jika pemasakan >1 menit, akan menyebabkan kualitas mi menurun yang ditandai dengan mi yang rapuh. Pemasakan yang terlalu lama akan menyebabkan pemborosan energi.

Perendaman menjadi CCP (Tabel 4) karena tahap ini kemungkinan terjadi kontaminasi silang (mikrobia dan logam berat) dari air yang digunakan untuk merendam. Pada tahap ini batas kritisnya yaitu penggunaan air yang bebas kontaminan dan higienis.

Penirisan menjadi CCP karena pada tahap ini kemungkinan terjadi kontaminasi silang (mikrobia dan lingkungan) yang bisa mengakibatkan mi sagu tercemar. Sehingga pada tahap ini proses penirisan harus menggunakan peralatan yang bersih dan sanitasi lingkungan tempat untuk meniriskan harus diperhatikan sehingga mikrobia tidak tumbuh dengan cepat. Kondisi penirisan harus seaseptis mungkin.

\subsection{Dokumentasi dan Verifikasi}

Setelah dianalisa bahaya dan penetapan CCP selesai dilakukan dan telah didokumentasikan dalam rencana $H A C C P$, maka tahap selanjutnya dilakukan penetapan prosedur dokumentasi dan verifikasi. Proses dokumentasi hendaknya dilakukan oleh dinas pertanian dengan dinas terkait, sedang proses verifikasi dapat dilakukan oleh penyuluh sekaligus menjadi proses audit untuk meyakinkan bermanfaatnya penerapan sistem HACCP yang telah disusun, sehingga cukup dengan mengendalikan proses-proses yang ditetapkan sebagai CCP. 


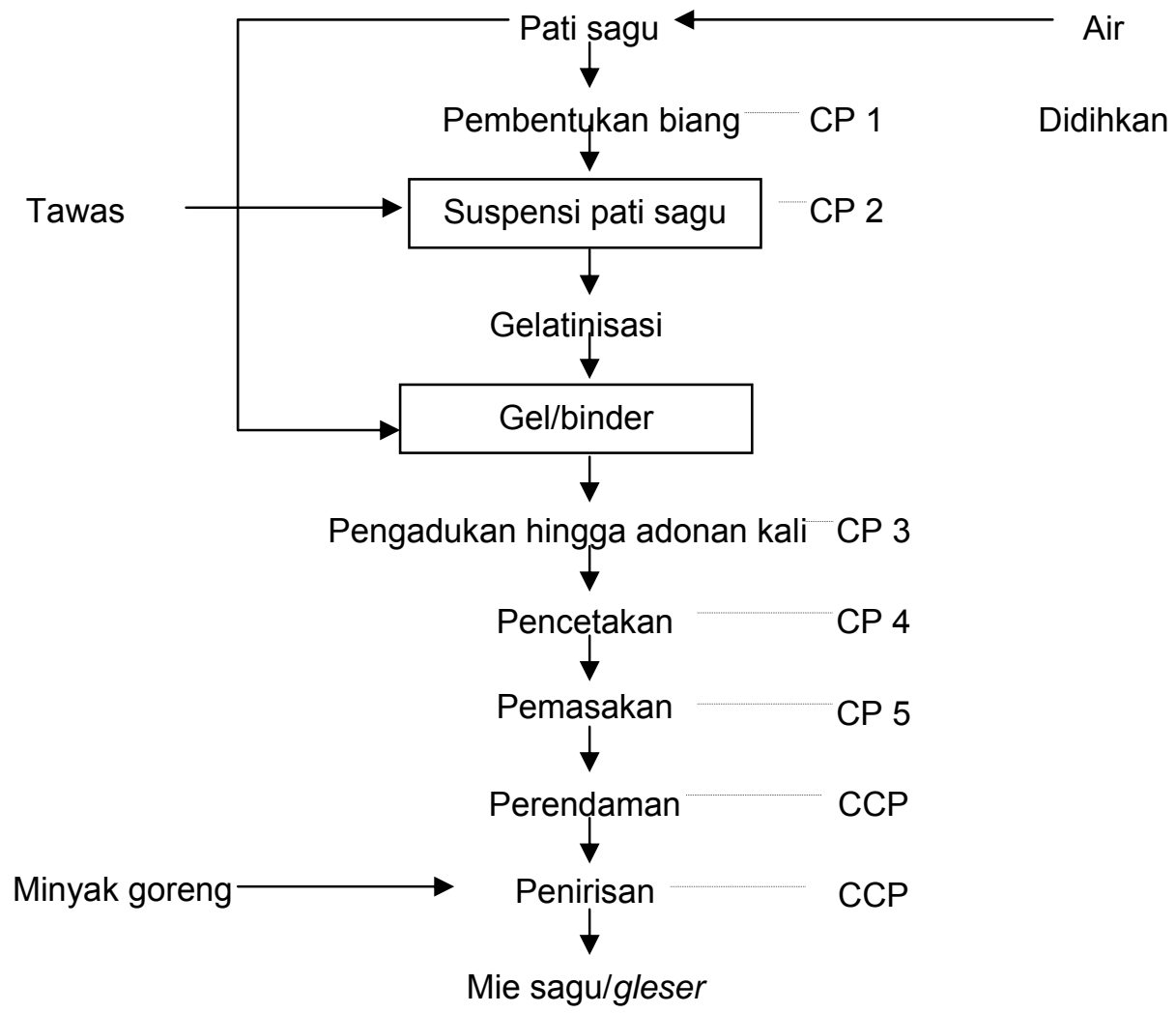

Gambar 3 Diagram Alir Pembuatan Mi

Tabel 2 Analisis Bahaya Proses Pembuatan Mi Sagu

\begin{tabular}{|c|c|c|c|c|c|c|c|c|c|}
\hline \multirow[b]{2}{*}{ No } & \multirow[b]{2}{*}{ Bahan Baku } & \multirow[b]{2}{*}{ Bahaya } & \multicolumn{2}{|c|}{ Bahaya terhadap } & \multirow[b]{2}{*}{$\begin{array}{c}\text { Penyebab } \\
\text { bahaya }\end{array}$} & \multicolumn{3}{|c|}{ Penting tidaknya } & \multirow[b]{2}{*}{$\begin{array}{c}\text { Tindakan } \\
\text { Pengendalian }\end{array}$} \\
\hline & & & $\begin{array}{l}\text { Kesela } \\
\text { matan }\end{array}$ & Mutu & & $\begin{array}{c}\text { Peluang } \\
\text { (T/S/R) }\end{array}$ & $\begin{array}{c}\text { Kepara } \\
\text { han } \\
\text { (T/S/R) }\end{array}$ & $\begin{array}{l}\text { Penting } \\
\text { /Tidak } \\
\text { (T/S/R) }\end{array}$ & \\
\hline 1. & $\begin{array}{l}\text { Pembuatan } \\
\text { Biang }\end{array}$ & $\begin{array}{l}\text { K: Logam berat } \\
\text { M: bakteri E.coli, } \\
\text { Shigella sp., V. } \\
\text { cholerae;kontamin } \\
\text { asi silang } \\
\text { peralatan \&tangan }\end{array}$ & - & $\sqrt{ }$ & $\begin{array}{l}\mathrm{K}: \text { residu } \\
\text { logam berat dlm } \\
\text { air } \\
\mathrm{M}: \text { kontaminasi } \\
\text { selama proses } \\
\text { pengeringan }\end{array}$ & $\begin{array}{l}\mathrm{T} \\
\mathrm{T}\end{array}$ & $\begin{array}{l}\mathrm{T} \\
\mathrm{T}\end{array}$ & $\begin{array}{l}\mathrm{T} \\
\mathrm{T}\end{array}$ & $\begin{array}{l}\text { penggunaan } \\
\text { air utk } \\
\text { perendaman, } \\
\text { pencucian, yg } \\
\text { bersih dan } \\
\text { higienis }\end{array}$ \\
\hline 2. & $\begin{array}{l}\text { Suspensi pati } \\
\text { sagu }\end{array}$ & $\begin{array}{l}\text { K: bahan pewarna } \\
\text { \& pengeras }\end{array}$ & - & $\sqrt{ }$ & $\begin{array}{l}\mathrm{K}: \text { pewarna } \\
\text { sintetis yang } \\
\text { bukan untuk } \\
\text { makanan; } \\
\text { penggunaan } \\
\text { tawas yang } \\
\text { berlebihan }\end{array}$ & $\mathrm{R}$ & $\mathrm{R}$ & $\mathrm{R}$ & $\begin{array}{l}\text { menimbang } \\
\text { dgn benar }\end{array}$ \\
\hline 3. & Gelatinisasi & \multicolumn{8}{|c|}{ Tidak teridentifikasi bahaya } \\
\hline 4. & Gel/Binder & \multicolumn{8}{|c|}{ Tidak teridentifikasi bahaya } \\
\hline 5. & Pengadukan & $\begin{array}{l}\text { M : kontaminasi } \\
\text { silang dengan } \\
\text { peralatan }\end{array}$ & - & $\sqrt{ }$ & $\begin{array}{l}\text { M : Peralatan } \\
\text { yang tidak } \\
\text { bersih dan } \\
\text { higienis }\end{array}$ & $\mathrm{R}$ & $\mathrm{R}$ & $\mathrm{R}$ & $\begin{array}{l}\text { Cuci peralatan } \\
\text { sampai bersih }\end{array}$ \\
\hline 6. & Pencetakan & $\begin{array}{l}\text { M : kontaminasi } \\
\text { silang dengan } \\
\text { peralatan }\end{array}$ & - & $\sqrt{ }$ & $\begin{array}{l}\text { M : Peralatan } \\
\text { yang tidak } \\
\text { bersih dan } \\
\text { higienis }\end{array}$ & $\mathrm{R}$ & $\mathrm{R}$ & $\mathrm{R}$ & $\begin{array}{l}\text { Cuci peralatan } \\
\text { sampai bersih }\end{array}$ \\
\hline 7. & Pemasakan & $\begin{array}{l}\mathrm{K} \text { : logam berat } \\
\mathrm{M} \text { : bakteri E.coli, } \\
\text { Shigella sp., } \mathrm{V} . \\
\text { cholerae }\end{array}$ & $\sqrt{ }$ & $\sqrt{ }$ & $\begin{array}{l}\mathrm{K}: \text { Residu } \\
\text { logam berat dlm } \\
\text { air } \\
\mathrm{M}: \text { Sbr air yg } \\
\text { digunakan tdk }\end{array}$ & $\mathrm{S}$ & $\mathrm{S}$ & $\mathrm{S}$ & $\begin{array}{l}\text { tidak } \\
\text { menggunakan } \\
\text { air kotor; } \\
\text { tidak } \\
\text { menggunakan }\end{array}$ \\
\hline
\end{tabular}




\begin{tabular}{|c|c|c|c|c|c|c|c|c|c|}
\hline \multirow[b]{2}{*}{ No } & \multirow[b]{2}{*}{ Bahan Baku } & \multirow[b]{2}{*}{ Bahaya } & \multicolumn{2}{|c|}{ Bahaya terhadap } & \multirow[b]{2}{*}{$\begin{array}{c}\text { Penyebab } \\
\text { bahaya }\end{array}$} & \multicolumn{3}{|c|}{ Penting tidaknya } & \multirow[b]{2}{*}{$\begin{array}{c}\text { Tindakan } \\
\text { Pengendalian }\end{array}$} \\
\hline & & & $\begin{array}{l}\text { Kesela } \\
\text { matan }\end{array}$ & Mutu & & $\begin{array}{l}\text { Peluang } \\
\text { (T/S/R) }\end{array}$ & $\begin{array}{c}\text { Kepara } \\
\text { han } \\
\text { (T/S/R) }\end{array}$ & $\begin{array}{l}\text { Penting } \\
\text { /Tidak } \\
\text { (T/S/R) }\end{array}$ & \\
\hline & & & & & bersih & & & & $\begin{array}{l}\text { air permukaan; } \\
\text { merebus air } \\
\text { sampai } \\
\text { matang }\end{array}$ \\
\hline 8. & Perendaman & $\begin{array}{l}\text { M : Kontaminasi } \\
\text { silang dengan } \\
\text { mikrobia dan } \\
\text { logam berat }\end{array}$ & $\sqrt{ }$ & $\sqrt{ }$ & $\begin{array}{l}\text { M : Adanya } \\
\text { kontaminasi } \\
\text { silang dari } \\
\text { mikrobia akibat } \\
\text { air yang } \\
\text { digunakan }\end{array}$ & $\mathrm{T}$ & $\mathrm{T}$ & $\mathrm{T}$ & $\begin{array}{l}\text { Gunakan air } \\
\text { masak dan } \\
\text { bersih; tempat } \\
\text { perendaman } \\
\text { harus higienis; } \\
\text { sanitasi } \\
\text { diperhatikan }\end{array}$ \\
\hline 9. & Penirisan & $\begin{array}{l}\text { M : Kontaminasi } \\
\text { silang dengan } \\
\text { mikrobia dan } \\
\text { logam berat }\end{array}$ & $\sqrt{ }$ & $\sqrt{ }$ & $\begin{array}{l}\text { M : Adanya } \\
\text { kontaminasi } \\
\text { silang dari } \\
\text { mikrobia akibat } \\
\text { air yang } \\
\text { digunakan }\end{array}$ & $\mathrm{T}$ & $\mathrm{T}$ & $\mathrm{T}$ & $\begin{array}{l}\text { Gunakan air } \\
\text { masak dan } \\
\text { bersih; tempat } \\
\text { perendaman } \\
\text { harus higienis; } \\
\text { sanitasi } \\
\text { diperhatikan }\end{array}$ \\
\hline
\end{tabular}

Keterangan: K : Kimia; M : Mikrobiologi; F : Fisik; T : Tinggi; S : Sedang; R : Rendah.

Tabel 3 Matrik CP pada Bahan Baku Mi Sagu

\begin{tabular}{|c|c|c|c|c|c|c|}
\hline \multirow[t]{2}{*}{ Tahap } & \multirow{2}{*}{$\begin{array}{l}\text { CP } \\
\text { No. }\end{array}$} & \multirow[t]{2}{*}{ Jenis Bahaya } & \multirow[t]{2}{*}{ Batas Kritis } & \multicolumn{2}{|c|}{ Monitoring } & \multirow{2}{*}{$\begin{array}{c}\text { Tindakan } \\
\text { Koreksi }\end{array}$} \\
\hline & & & & Metode & Frekuensi & \\
\hline $\begin{array}{l}\text { Pembentukan } \\
\text { Biang }\end{array}$ & 1 & $\begin{array}{l}\text { Kimia } \\
\text { Biologi }\end{array}$ & $\begin{array}{l}\text { Sumber air } \\
\text { yang } \\
\text { digunakan } \\
\text { bersih bebas } \\
\text { mikrobia }\end{array}$ & $\begin{array}{l}\text { Cek } \\
\text { sumber } \\
\text { air }\end{array}$ & $\begin{array}{l}\text { Setiap } \\
\text { proses }\end{array}$ & $\begin{array}{l}\text { Ganti air dengan } \\
\text { air yang benar- } \\
\text { benar bersih }\end{array}$ \\
\hline $\begin{array}{l}\text { Suspensi pati } \\
\text { sagu }\end{array}$ & 2 & Kimia & $\begin{array}{l}\text { Pemilihan } \\
\text { pewarna } \\
\text { yang tepat } \\
\text { dan } \\
\text { penimbangan } \\
\text { yang akurat }\end{array}$ & $\begin{array}{l}\text { Cek } \\
\text { kesigapan } \\
\text { operator }\end{array}$ & $\begin{array}{l}\text { Setiap } \\
\text { proses }\end{array}$ & $\begin{array}{lr}\text { Lakukan } & \text { kembali } \\
\text { proses } & \text { yang } \\
\text { benar } & \end{array}$ \\
\hline Pengadukan & 3 & Biologi & $\begin{array}{l}\text { Peralatan } \\
\text { yang } \\
\text { digunakan } \\
\text { bersih }\end{array}$ & $\begin{array}{l}\text { Pastikan } \\
\text { peralatan } \\
\text { yang } \\
\text { digunakan } \\
\text { bersih }\end{array}$ & $\begin{array}{l}\text { Setiap } \\
\text { proses }\end{array}$ & $\begin{array}{l}\text { Cuci peralatan } \\
\text { sampai bersih }\end{array}$ \\
\hline Pencetakan & 4 & Biologi & $\begin{array}{l}\text { Peralatan } \\
\text { yang } \\
\text { digunakan } \\
\text { bersih }\end{array}$ & $\begin{array}{l}\text { Pastikan } \\
\text { peralatan } \\
\text { yang } \\
\text { digunakan } \\
\text { bersih }\end{array}$ & $\begin{array}{l}\text { Setiap } \\
\text { proses }\end{array}$ & $\begin{array}{l}\text { Cuci peralatan } \\
\text { sampai bersih }\end{array}$ \\
\hline Pemasakan & 5 & Kimia & $\begin{array}{l}\text { Sumber air } \\
\text { yang } \\
\text { digunakan } \\
\text { bersih bebas } \\
\text { kontaminan } \\
\text { logam berat }\end{array}$ & $\begin{array}{l}\text { Cek } \\
\text { sumber } \\
\text { air }\end{array}$ & $\begin{array}{l}\text { Setiap } \\
\text { proses }\end{array}$ & $\begin{array}{l}\text { Ganti air dengan } \\
\text { air yang benar- } \\
\text { benar bersih }\end{array}$ \\
\hline
\end{tabular}


Tabel 4 Matrik CCP pada Proses Pengolahan Mi Sagu

\begin{tabular}{|c|c|l|l|l|l|l|}
\hline Tahap & $\begin{array}{l}\text { CP } \\
\text { No. }\end{array}$ & Jenis Bahaya & Batas Kritis & \multicolumn{2}{|c|}{ Monitoring } & \multicolumn{1}{|c|}{$\begin{array}{c}\text { Tindakan } \\
\text { Koreksi }\end{array}$} \\
\hline Perendaman & 1 & Kimia & $\begin{array}{l}\text { Sumber air } \\
\text { yang } \\
\text { digunakan } \\
\text { bersih, bebas } \\
\text { mikrobia dan } \\
\text { kontaminan } \\
\text { logam berat }\end{array}$ & $\begin{array}{l}\text { Metode } \\
\text { sumber } \\
\text { air dan } \\
\text { aunakan } \\
\text { air } \\
\text { matang }\end{array}$ & $\begin{array}{l}\text { Fetiap } \\
\text { proses }\end{array}$ & $\begin{array}{l}\text { Ganti air dengan } \\
\text { air yang benar- } \\
\text { benar bersih; } \\
\text { masak air } \\
\text { sampai matang }\end{array}$ \\
\hline Penyajian & 2 & Kimia & $\begin{array}{l}\text { Peralatan } \\
\text { yang } \\
\text { digunakan } \\
\text { bersih, } \\
\text { sanitasi } \\
\text { lingkungan }\end{array}$ & $\begin{array}{l}\text { Pastikan } \\
\text { peralatan } \\
\text { yang } \\
\text { digunakan } \\
\text { bersih }\end{array}$ & $\begin{array}{l}\text { Setiap } \\
\text { proses }\end{array}$ & $\begin{array}{l}\text { Cuci peralatan } \\
\text { sampai bersih }\end{array}$ \\
\hline
\end{tabular}

\section{KESIMPULAN}

4.1 Hasil studi HACCP terhadap proses pengolahan mi sagu maka ditetapkan satu bahan baku yang termasuk CCP yaitu pati sagu.

4.2 Pada proses produksi mi sagu terdapat 2 tahap yang termasuk CCP dan 5 tahap yang termasuk CP. Tahapan yang termasuk CCP yaitu perendaman dan penirisan. Sedangkan tahapan yang termasuk CP yaitu pembentukan biang, suspensi pati sagu, pengadukan, pencetakan, dan pemasakan.

\section{DAFTAR PUSTAKA}

1. Bryan, 1992. Hazard Analysis Critical Control Point Evaluations, World Health Organization. Geneva

2. BSN, 1999, Pedoman Penyusunan Rencana Sistem Analisa Bahaya dan Pengendalian Titik Kritis (HACCP). Badan Standardisasi Nasional. Pedoman 1004-1999.

3. Schmitt, R.; Bryan F.L.; Jermini,M.; Chilufya, A.N.; Hakalima, A.T.; Zyuulu, M.; Mfume, E.; Mwande, C.; Mullungushi, E.; dan Lubasi, D. 1997. Hazard and Critical Control Point of Food Preparation in Homes in Which Person Had Diarrhea in Zambia. J. Food Protein. 60:2:161-171.

4. SNI. 1998. SNI 01-4852-1998 : Sistem Analisa Bahaya dan Pengendalian Titik Kritis. Departemen Perindustrian Indonesia
5. Waryat; Tessar Ramdhan; dan Syarifah Aminah. 2004. Studi HACCP pada Proses Pembuatan Minuman Tradisional Betawi "Bir Pletok Cair". Prosiding Seminar Nasional Peningkatan Daya Saing Pangan Tradisional. BB Pasca Panen Pertanian: 98108.

\section{BIODATA}

Miskiyah, S.Pt.M.P., dilahirkan di Blora pada tanggal 3 Desember 1970. Penulis menyelesaikan pendidikan S2 Bidang IImu dan Teknologi Pangan Universitas Gadjah Mada Yogyakarta. Sekarang penulis bekerja sebagai staf peneliti di Balai Besar Penelitian dan Pengembangan Pascapanen Pertanian, Departemen Pertanian.

Widaningrum, dilahirkan di Sukabumi pada tanggal 7 April 1979. Penulis menyelesaikan pendidikan S1 Bidang Teknologi Pangan, FATETA, IPB. Sekarang penulis bekerja sebagai staf peneliti di Balai Besar Penelitian dan Pengembangan Pasca Panen Pertanian, Departemen Pertanian.

Heti Herawati, SSi., dilahirkan di Sukabumi pada tanggal 22 Februari $1966 . \quad$ Penulis menyelesaikan pendidikan S1 bidang Kimia Universitas Pakuan. Sekarang penulis bekerja sebagai staf peneliti di Balai Besar Penelitian dan Pengembangan Pascapanen Pertanian, Departemen Pertanian. 